\title{
Production of Herbicide-Resistant Coffee Plants (Coffea canephora P.) via Agrobacterium tumefaciens-Mediated Transformation
}

\author{
Alessandra Ferreira Ribas ${ }^{1}$, Adilson Kenji Kobayashi ${ }^{2}$, Luiz Filipe Protasio Pereira ${ }^{3}$ and \\ Luiz Gonzaga Esteves Vieira ${ }^{1 *}$ \\ ${ }^{1}$ Laboratório de Biotecnologia Vegetal; Instituto Agronômico do Paraná; lvieira@iapar.br; C. P. 481; 86001-970; \\ Londrina - PR - Brasil. ${ }^{2}$ Embrapa Mandioca e Fruticultura; C. P. 007; 44380-000; Cruz das Almas - BA - Brasil. \\ ${ }^{3}$ Embrapa Café; Instituto Agronômico do Paraná; C. P. 481; 86001-970; Londrina - PR - Brasil
}

\begin{abstract}
Transgenic plants of Coffea canephora P. resistant to the herbicide ammonium glufosinate were regenerated from leaf explants after co-culture with Agrobacterium tumefaciens strain EHA105 harboring pCambia3301, a plasmid that contains the bar and the uidA genes both under control of $35 \mathrm{~S}$ promoter. Direct somatic embryogenesis was induced on basal medium contained 1/4 strength macro salts and half strength micro salts of MS medium, organic constituents of $B_{5}$ medium and 30 g. $L^{-1}$ sucrose supplemented with $5 \mu M N^{6}-(2$-isopentenyl)-adenine (2-iP). Ten $\mu M$ ammonium glufosinate was used for putative transgenic somatic embryos selection. Presence and integration of the bar gene were confirmed by PCR and Southern blot analysis. Selected transgenic coffee plants sprayed with up to $1600 \mathrm{mg}^{-L^{-1}}$ of Finale ${ }^{T M}$, a herbicide containing glufosinate as the active ingredient, retained their pigmentation and continued to grow normally during ex vitro acclimation.
\end{abstract}

Key words: Genetic transformation, coffee, herbicide tolerance, ammonium glufosinate

\section{INTRODUCTION}

Coffee is one the most important commodities in the world with a global market value of 70 to 80 billion US\$/year. It is the world's most important beverage and upon which the economy of many developing countries depends. The most commercially important species are Arabica coffee (C. arabica), Robusta coffee (C. canephora) and to a lesser extent Liberica coffee $(C$. liberica) and Excelsea coffee (C. dewevrei). Arabica and Robusta coffees represent more than $70 \%$ and $25 \%$ of the world's coffee production, respectively. $C$. canephora is mostly planted in low altitudes and warm climates in West and Central Africa, throughout Southeast Asia, and parts of South America, including Brazil, the second largest world producer of Robusta coffee. In many of these coffee growing areas, coffee production is affected by pests, diseases and the lack of an effective weed control procedure.

Coffee trees are extremely sensitive to weed competition, mainly during the rainy season when production losses can reach very high values (Blanco et al., 1982). Herbicide tolerant germoplasm has not been identified in Coffea species; consequently, conventional plant breeding for herbicide-tolerant varieties is not possible.

* Author for correspondence 
Therefore, molecular breeding offers interesting perspectives towards the production of coffee varieties tolerant to herbicide.

The first experiments on coffee transformation used kanamycin as selective agent. Although the antibiotic resistance gene (nptII) has been detected in putative transgenic tissue, plant regeneration was not achieved (Barton et al., 1991; Feng et al., 1992). Using both antibiotics kanamycin and hygromycin, Hatanaka et al. (1999) regenerated transgenic coffee plants form $C$. canephora. The herbicide chlorsulfuron has also been used as selectable maker for coffee system transformation (Leroy et al., 2000).

Studying the selection system on genetic transformation of coffee, van Boxtel et al. (1995) assayed five selective agents (ammonium glufosinate, chorsulfuron, glyphosate, kanamycin and hygromycin) and showed the herbicide ammonium glufosinate as the most promising agent for selecting stable transformants from coffee tissues.

Ammonium glufosinate, the chemically synthesized phosphinothricin (PPT), is used as non selective pre-emergence herbicide and also for pre-harvest desiccation (Botterman \& Leemans, 1988). Phosphinotricin is an irreversible inhibitor of glutamine synthetase (GS), the only enzyme that detoxifies ammonia produced during nitrate reduction, photorespiration and amino acid degradation in plant cells (D'Haullin et al., 1992). Inhibition of GS causes a rapid buildup of intracellular ammonia in leaves and an associated disruption of photosynthesis and plant cell death (Devine et al., 1993).

Plant tolerance to ammonium glufosinate has been obtained by using two bacterial genes - bar and pat - isolated from Streptomyces hygroscopicus and S. viridochromogenes Tü494 (Murakami et al., 1986; Strauch et al., 1988) respectively. The enzyme phosphinothricin- $\mathrm{N}$-acetyltransferase (PAT) encoding by theses genes acetylates the free $\mathrm{NH}_{2}$ group of PPT causing its inactivation and thereby prevents autotoxicity in the producing organism (D'Haullin et al., 1992; Metz et al., 1998). Ammonium glufosinate resistance is not only important as selectable marker for in vitro studies and development of transgenic plants but also for weed control and hybrid seed production (Metz et al., 1998).

This work describes the production of herbicidetolerant $C$. canephora plants expressing the bar gene which confers resistance to ammonium glufosinate via Agrobacterium tumefaciens gene transfer.

\section{MATERIALS AND METHODS}

\section{Explant source and culture conditions}

Young and completely expanded leaves collected from field grown plants of $C$. canephora $\mathrm{P}$. clone LMC 82-6. were used as explant source. The leaves were washed with running tap water, surface sterilized in $70 \%$ (v/v) ethanol for few seconds and immersed in a commercial sodium hypochlorite solution (1\%) for $30 \mathrm{~min}$. The leaves were rinsed four times in sterile distilled water. The explants were cut $\left(1 \mathrm{~cm}^{2}\right)$ in a solution of cystein $250 \mathrm{mg} . \mathrm{L}^{-1}$ and placed in Petri dishes (90 $\mathrm{mm} \quad \mathrm{x} \quad 10 \mathrm{~mm})$ containing direct somatic embryogenic medium - DE (Hatanaka et al., 1991) supplemented with $5 \mu \mathrm{M} 2-\mathrm{iP}, 3 \%$ sucrose and solidified with $8 \mathrm{~g} . \mathrm{L}^{-1}$ agar. The $\mathrm{pH}$ was adjusted to 5.7 and the medium was sterilized at $120^{\circ} \mathrm{C}$ for $20 \mathrm{~min}$. Ten explants were cultured in each Petri dish with the adaxial surface in contact with the medium. The Petri dishes were kept in the dark at $27 \pm 2^{\circ} \mathrm{C}$ for 3 weeks prior to inoculation with $A$. tumefaciens.

\section{Plant transformation}

The disarmed A. tumefaciens strain EHA105 with the binary plasmid pCambia3301 (Center for the Application of Molecular Biology to International Agriculture - Canberra, Australia) was used for genetic transformation. The pCambia3301 plasmid contains the uidA reporter gene (Jefferson et al., 1987) encoding $\beta$-glucuronidase (GUS) and the gene bar (DeBlock et al., 1987) that encodes phosphinothricin acetyltransferase (PAT), both driven by the CaMV-35S promoter.

A single colony of bacteria was inoculated on YMB medium (Hooykaas et al., 1977) containing $30 \mathrm{mg} . \mathrm{L}^{-1}$ kanamycin plus $20 \mathrm{mg} . \mathrm{L}^{-1}$ rifampycin and incubated in an orbital shaker $(150 \mathrm{rpm})$ at $27^{\circ} \mathrm{C}$ overnight. After three weeks of pre-culture under the conditions described earlier, the explants were immersed on Agrobacterium suspension (absorbance of 0.2 at $600 \mathrm{~nm}$ ) with $0.2 \mathrm{mM}$ acetosyringone, submitted to a sonication pulse (2 s) and left $30 \mathrm{~min}$ in suspension. The explants were co-cultivated on solidified somatic direct embryogenic medium in the dark for 4 days and then transferred to the same medium supplemented 
with $10 \mu \mathrm{M}$ ammonium glufosinate and $400 \mathrm{mg} . \mathrm{L}^{-}$

${ }^{1}$ cefotaxime for induction of embriogenic calli and selective regeneration of transformed embryos. After six months, embryogenic calli were isolated and sub-cultured on the same selective medium until the development of plantlets.

\section{Histochemical GUS assay}

Embryogenic tissue from explants in selective medium were vacuum infiltrated with $\mathrm{X}$-Gluc assay buffer ( $2 \mathrm{mM}$ X-Gluc, $100 \mathrm{mM}$ buffer phosphate ( $\mathrm{pH} 8.0$ ), $10 \mathrm{mM}$ EDTA, $1 \mathrm{mM} \mathrm{K}_{4} \mathrm{Fe}$ $(\mathrm{CN})_{6}, 1 \mathrm{mM} \mathrm{K} \mathrm{K}_{3} \mathrm{Fe}(\mathrm{CN})_{6}$ and $20 \%$ methanol. The embryogenic tissue were left to stain at $37^{\circ} \mathrm{C}$ overnight and fixed in a solution containing $10 \%$ acetic acid, $50 \%$ ethanol and $7.4 \%$ formaldehyde. The tissues were cleared in $70 \%$ ethanol and observed using a stereo microscope. Assays for GUS expression were also performed in leaves of greenhouse acclimatized plants.

Molecular analysis

Regenerated plants were initially analyzed by PCR. Small-scale extraction of DNA from leaves was carried out according to Doyle \& Doyle (1987). The primers used for amplification of the bar gene were: 5'-GTCTGCACCATGGTCAACC$3^{\prime}$ and 5'-GAAGTCCAGCTGCCAGAAAC-3'. PCR amplifications of DNA were performed in $20 \mu \mathrm{l}$ volumes containing $100 \mathrm{mM}$ Tris- $\mathrm{HCl}(\mathrm{pH}$ 8.0), $500 \mathrm{mM} \mathrm{KCl}, 25 \mathrm{mM} \mathrm{MgCl} 2,2.0 \mathrm{mM}$ of each dNTP, 10 pmol of primers, $1 \mathrm{U}$ of DNA polymerase and $100 \mathrm{ng}$ genomic DNA. The reaction mix for PCR was incubated in a MJ Research cycler as follows: $94^{\circ} \mathrm{C}$ for $4 \mathrm{~min}$, followed for 30 cycles of $1 \mathrm{~min}$ at $94^{\circ} \mathrm{C}, 1 \mathrm{~min}$ at $59^{\circ} \mathrm{C}, 1 \mathrm{~min}$ at $72^{\circ} \mathrm{C}$ with $5 \mathrm{~min}$ of final extension at $72^{\circ} \mathrm{C}$.

Southern blotting hybridization was performed to confirm the stable integration of the bar gene into the genome of the transgenic plants. Genomic DNA was extracted from greenhouse grown plants with the same protocol used for PCR. Twenty $\mu \mathrm{g}$ of DNA were digested with EcoRI and separated by electrophoresis in $0.8 \%$ agarose gel. After electrophoresis the gels was blotted onto nylon membranes by capillarity. The probe corresponding to the fragment of bar gene was ${ }^{32}$ P-labeled according to Sambrook et al. (1989). After overnight hybridization at $65^{\circ} \mathrm{C}$, the membranes were washed in $2 \mathrm{X}$ SSC, $0.1 \%$ SDS at room temperature and in $1 \mathrm{X} \mathrm{SSC,} 0.1 \% \mathrm{SDS}$ at $65^{\circ} \mathrm{C}$, and were exposed to X-ray film (Kodak ${ }^{\mathrm{TM}}$ ) for $48 \mathrm{~h}$.

\section{Herbicide resistance assays}

Transformed and non-transformed (control) plants maintained in the greenhouse for seven months, were sprayed to run-off (approximately $3 \mathrm{ml}$ per plant) with aqueous solutions of the commercial herbicide formulation (Finale ${ }^{\mathrm{TM}}$, AgrEvo) diluted to contain 200, 400, 8001200 and $1600 \mathrm{mg} . \mathrm{L}^{-1}$ ammonium glufosinate. The tolerance of plants to the herbicide was evaluated visually one week after herbicide application.

\section{RESULTS AND DISCUSSION}

There are few works reporting regeneration of transgenic coffee plants (Hatanaka et al., 1999; Spiral et al., 1999; Leroy et al., 2000). Spiral et al. (1993) reported difficulties in screening transformation events in coffee with the kanamycin selection system. On the other hand, Hatanaka et al. (1999) obtained transformed plants of $C$. canephora using a combination of two antibiotics (hygromicin and kanamycin). The use of marker genes giving resistance to herbicide has also been successfully applied by Leroy et al. (2000) for selecting transformed coffee plants using somatic embryos as initial explants. They produced transgenic plants of $C$. canephora and $C$. arabica resistant to the leaf miner using the herbicide chlorsulfuron as selective agent.

In this work the disarmed strain EHA105 harboring the binary plasmid pCambia3301, which carries the bar gene for ammonium glufosinate resistance, was used for transformation of 118 coffee leaves explants (Fig. 1A). Embryogenic tissue induction was obtained on ammonium glufosinate containing medium $(10 \mu \mathrm{M})$ within four months following infection with $A$. tumefaciens (Fig. 1B). By comparison, most non co-cultivated control explants were necrotic and did not develop embryogenic calli.

Putatively transformed calli were subcultured monthly onto fresh DE media containing glufosinate. A total of forty-five embryogenic calli resistant to ammonium glufosinate were produced (Fig. 1C and D). Histochemical assays were performed in small sections dissected from the putative transformed embryogenic calli to detect GUS activity. Among these calli, 82\% showed 
GUS-positive reaction (Fig. 2A), while the controls (non-transformed calli) did not show any uidA expression. Differently to previous reports (van Boxtel et al., 1995; Spiral et al., 1999; Hatanaka et al., 1999), endogenous GUS activity was not observed on the assayed coffee somatic embryogenic tissues. The use of methanol in the GUS assay may have helped to avoid eventual endogenous GUS activity (Kosugi et al., 1990).

Hatanaka et al. (1999) reported that $36 \%$ of the coffee calli growing on selective medium with 5 mg. $\mathrm{L}^{-1}$ hygromycin showed GUS-positive reaction. When a marker gene for resistance to chorsulfuron was used for transformation it was possible to detect GUS-positive reaction on $50 \%$ of coffee embryogenic calli (Leroy et al., 2000). Therefore, our results showed that the ammonium glufosinate concentration used in the culture medium was very effective for selecting transformed tissues. The embryogenic calli converted on numerous somatic embryos and regenerated several plantlets (Fig. 2B). GUS assay, PCR, Southern analysis and Finale ${ }^{\mathrm{TM}}$ spraying were used to evaluate $\mathrm{T} 0$ plants.

The blue staining was preferentially detected near wounded areas (Fig. 2C).
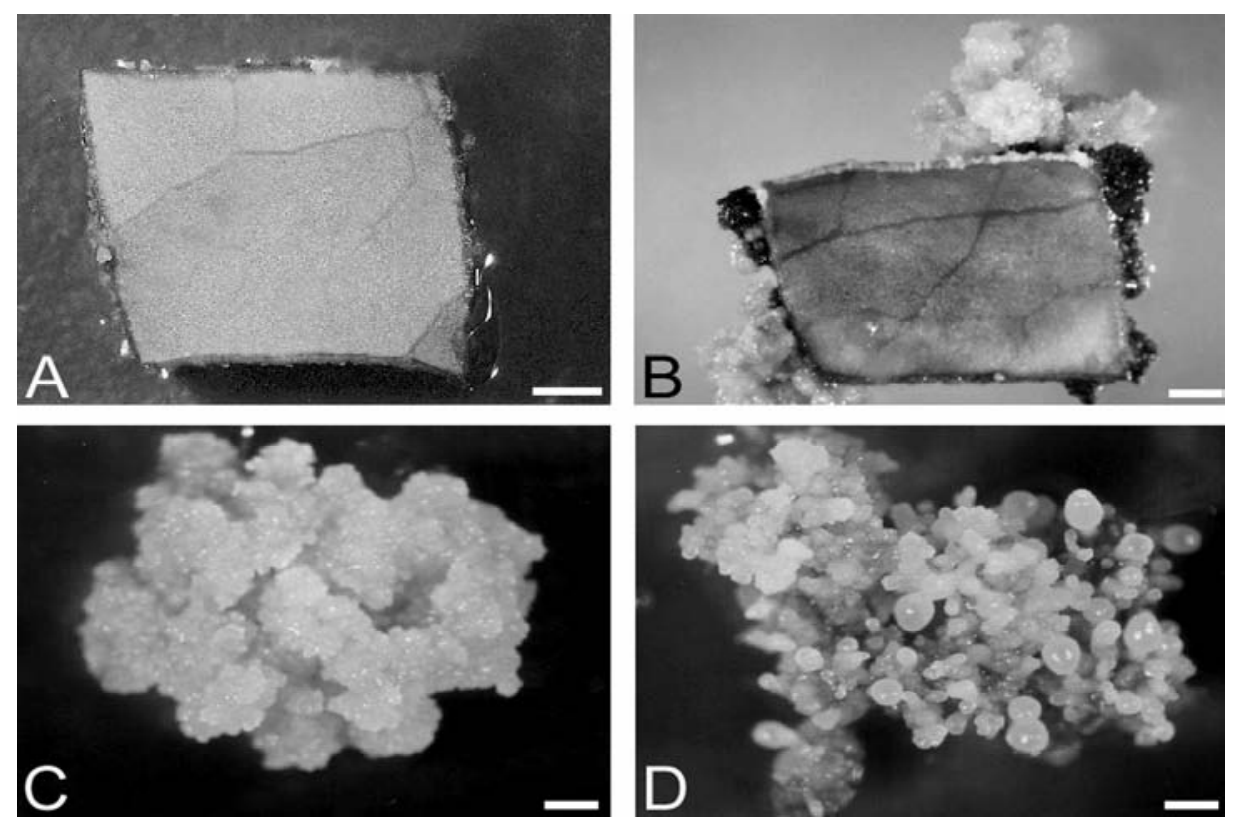

Figure 1 - Steps of the strategy used for transfering the bar gene to $C$. canephora. A- Leaf explant used for somatic embryogenesis induction on DE medium with $5 \mu \mathrm{M} 2$ 2-iP; $B$ - Leaf explant with embryogenic coffee callusing on DE medium with $10 \mu \mathrm{M}$ ammonium glufosinate four months after co-cultivation with A. tumefaciens; $C$-Putative transformed embryogenic callus isolated for somatic embryo development on the same medium without 2iP; $D$ - Putative transgenic embryos at different stages of development, globular to heart stage on DE medium without 2-iP. Scale bar $=1 \mathrm{~mm}$.

Surgical wounding of leaf surfaces increased the staining intensity, suggesting a blocking effect of the well-developed cuticle of the coffee leaf (Hatanaka et al., 1999). Control plantlets (nontransformed) did not show any GUS-like activity.

DNA samples from GUS positive T0 plants were subjected to PCR analysis to detect the presence of the bar gene. All plants expressing uidA gene also revealed the presence of bar gene by showing the expected 450 bp amplified fragment (Fig. 3A). PCR amplification products were not obtained with DNA from leaf-derived non-transformed control plants. Southern blot analysis of genomic DNA was conducted in nine plants regenerated from three different calli to confirm the stable integration of the bar gene on coffee genome and to estimate the gene copy number present in the transgenic coffee plants. The genomic DNA was 
digested with enzyme EcoRI and hybridized with bar gene probe. As EcoRI cuts once within pCambia3301, the number of bands obtained was thus indicative of the number of transgene integration sites.

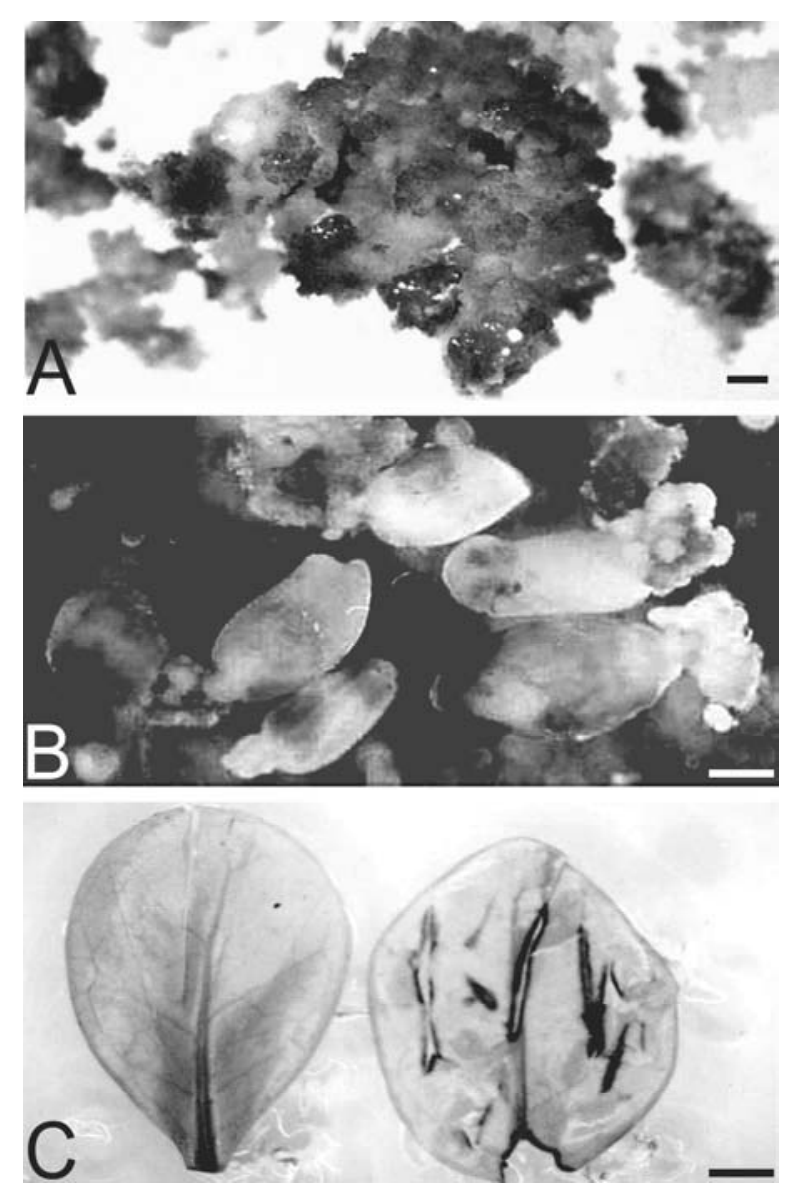

Figure 2 - Histochemical GUS assay. $A$ - Embryogenic tissue; $B$ - Somatic embryos; $C$ - Leaves of in vitro grown plants: left, control plant; right, transgenic plant. Scale bar $=1 \mathrm{~mm}$.

The results showed the integration of independent single copy inserts of the bar gene in all plants originated from the different calli analyzed (Fig. 3B). Leroy et al. (2000) observed that among 51 events of transgenic coffee plants transformed via Agrobacterium 69\% also presented only one TDNA copy. The transgenic coffee plants presented normal phenotype during the vegetative phase and produced viable seeds (data not shown).

This is in agreement with previous work, in which C. canephora transformed with A. tumefaciens presented normal phenotype while plants transformed with A. rhizogenes showed several different undesirable traits, such as short internodes and crinkled leaves (Spiral et al., 1999). Expression of the bar gene was verified by localized application of herbicide on in vivo acclimated plants. Leaves of transgenic plants and non-transformed controls planted in a greenhouse were sprayed with different concentrations of herbicide (Finale ${ }^{\mathrm{TM}}$ ) and scored for herbicide damage. In non-transformed plants, spray application of $200 \mathrm{mg} . \mathrm{L}^{-1}$ ammonium glufosinate resulted in necrosis of the sprayed area after $48 \mathrm{~h}$ or in some cases death of the entire plant after few days (Fig. 4). In contrast, transgenic plants did not show any damage even at the concentration of 800 mg. $L^{-1}$. Small necrotic spots and a slight loss of pigmentation were observed in the abaxial surface of leaves only when 1200 and $1600 \mathrm{mg} . \mathrm{L}^{-1}$ of the ammonium glufosinate were used (data not shown). But even at these high herbicide concentrations, all the transgenic plants recovered 
from injury and continued to grow, showing that the plants expressing bar gene tolerated eight times the concentration of ammonium glufosinate required to kill a non-transformed plant.

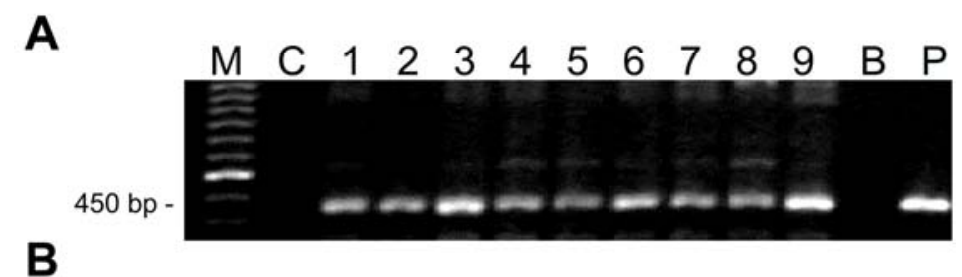

B

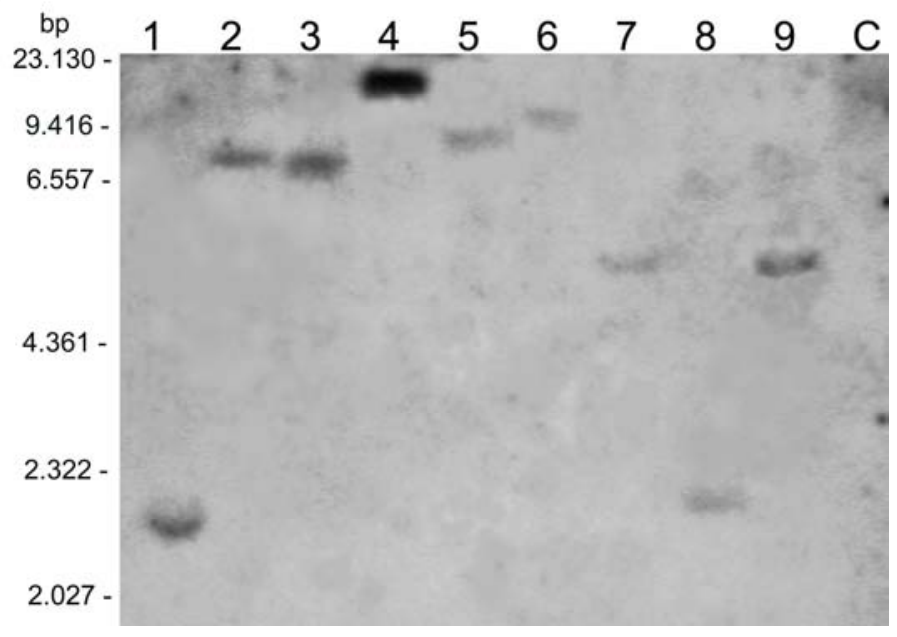

Figure 3 - Molecular analysis of transgenic C. canephora plants. A- PCR analysis of 9 transgenic plants (1-9) and of a non-transformed control plant $(C)$. $M$, molecular marker $100 \mathrm{bp}$ ladder; $B$, blank mix without DNA; $P$, pCambia 3301 plasmid; Arrow, expected 450 bp amplified fragment of bar gene. $B$ - Southern blot analysis of DNA from ammonium glufosinate-tolerant $C$. canephora plants transformed with pCambia 3301. DNA was digested with EcoRI restriction enzyme and probed with the bar gene. 1-3, plants regenerated from callus $1 ; 4-6$, plants regenerated from callus $2 ; 7-9$, plants regenerated from callus $3 ; C$, control (non transformed).

As different crop plants could have different responses to this herbicide (Christou et al., 1991) and no information was available regarding a killing curve for coffee plants, the concentration of the ammonium glufosinate used was well above the ranges reported for other crops.

The high tolerance of the transgenic coffee plants to the herbicide achieved in this work could be important to facilitate weed control. Generally, tolerance to herbicide concentrations 4-10 times higher than the one used for killing weeds at field conditions are considered satisfactory to avoid crop injuries (De Block et al., 1987).

C. canephora growing areas are characterized by high rainfall and temperatures that favor the growth of diverse weed species. As a result, coffee growth, yield and quality are seriously reduced and weed control is one of the major cultural operations that entail high production costs (Friessienben et al., 1991). Coffee is very sensitive to weed competition and production losses caused by the lack of adequate weed control during raining periods have been estimated to reach as high as $35 \%$ depending on the type and the frequency of weeding operations (Jones \& Wallis, 1963).

In the past 20 years, coffee farmers in different coffee growing regions of the world have increasingly replacing low-density with highdensity planting coffee production, which suffers from diseases and insect problems and lack of a proper fertilization practices. High density planting of coffee trees offer possibilities for increasing farmers' income as a result of higher 
yield levels compared to the present method of wide space planting. However, the adoption of such management practices requires efficient weed control strategies, mainly at the early stages of crop establishment, which are usually carried out manual slashing, mulching, cover cropping and mechanical practices. Tillage normally restricts high-density coffee planting, since wide plant spacing is required to enable access to the crop; this is also costly in terms of labor and can result in significant crop damage. The inclusion of herbicides in an integrated weed management is a recommended practice for controlling weeds in high density coffee planting systems for an economically sustainable coffee production.

Unfortunately, current weed control practices for coffee plantations rely heavily on only a few and expensive herbicides because of their efficacy over a wide range of weed species and in different growth stages (Lorenzi, 1994). However, none of these herbicides can be sprayed directly on coffee plants because even at label application rates, contact with green stems or leaves can injure or kill coffee plants. Therefore, the cultivation of herbicide-tolerant coffee plants can facilitate the use of integrated weed management practices and reduce the need to undertake frequent crop tillage in the coffee production systems.
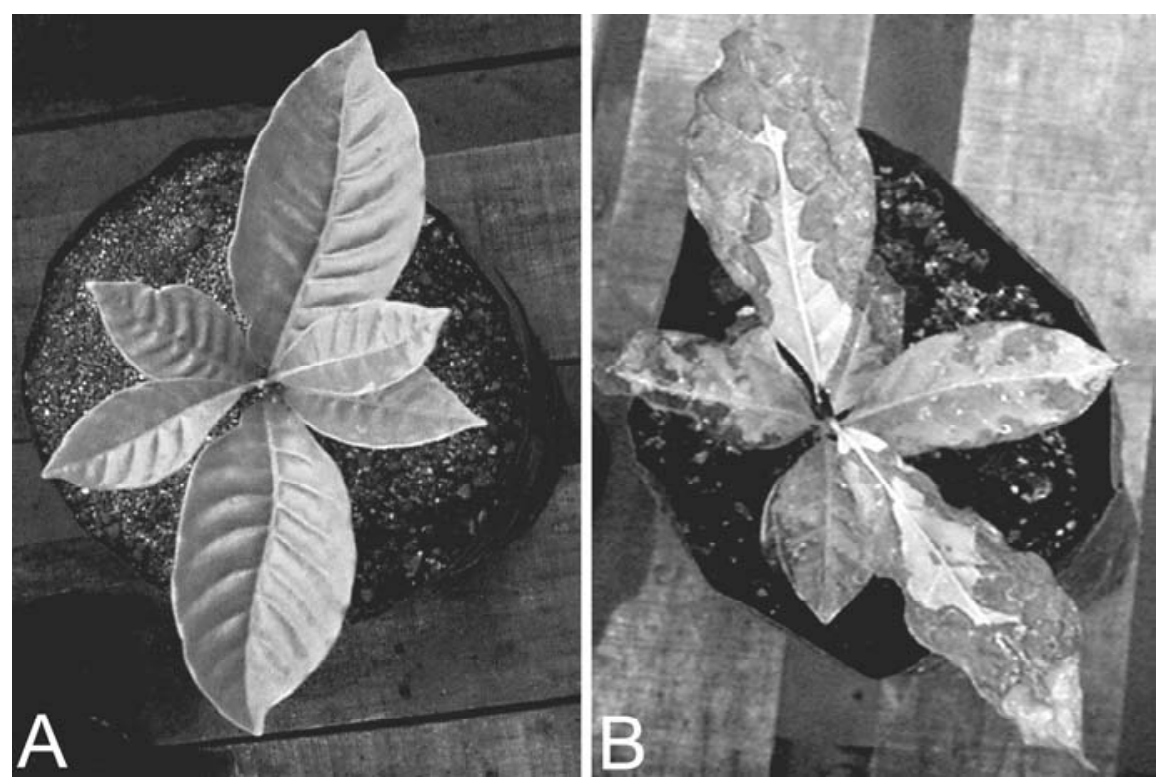

Figure 4 - Herbicide tolerance of greenhouse-grown transformed plants (A) and non-transformed plants (B), one week after spraying with Finale diluted to contain ammonium glufosinate at $200 \mathrm{mg} . \mathrm{L}^{-1}$

In conclusion, present results showed that transgenic coffee plants maintained under greenhouse conditions would survive spraying with ammonium glufosinate up to $1600 \mathrm{mg} . \mathrm{L}^{-1}$. Since these coffee plants survived herbicide concentrations well above of those usually applied in the field, these plants could be used in agricultural systems in which competing weeds could be controlled by spraying an herbicide to which the transgenic coffee crop is tolerant. Also, as the use of antibiotic resistance genes for selection of transgenic crops has resulted in particular public concern, the data obtained clearly demonstrated the utility of the bar gene for coffee genetic transformation using ammonium glufosinate as an alternative selective agent to genetically engineer this crop with modified traits for enhanced agricultural performance.

\section{ACKNOWLEDGEMENTS}

The authors are grateful to the Center for the Application of Molecular Biology to International Agriculture - Canberra, Australia for the donation of pCambia3301 plasmid. We also wish to thank the technical assistance provided by Ms. Fátima 
Borges Bustos and Mr. João Batista da Silva. This research was supported by the Consórcio Brasileiro de Pesquisa e Desenvolvimento do Café (CBP\&D-Café).

\section{RESUMO}

Plantas transgênicas de Coffea canephora $\mathrm{P}$ resistentes ao herbicida glufosinato de amônio foram regeneradas a partir de explantes foliares co-cultivados com Agrobacterium tumefaciens EHA105 contendo o plasmídio pCambia3301 que contém os genes bar e uidA ambos sob controle do promotor 35S. Embriogênese somática direta foi induzida no meio contendo $1 / 4$ da concentração de macro, metade da concentração de micronutrientes do meio MS, constituintes orgânicos do meio $\mathrm{B}_{5} \mathrm{e}$ 30 g. $\mathrm{L}^{-1}$ de sacarose suplementado com $5 \mu \mathrm{M} \mathrm{N}^{6}-$ (2-isopentenil)-adenina (2-iP) e $10 \quad \mu \mathrm{M} \quad \mathrm{de}$ glufosinato de amônio para seleção de embriões transgênicos putativos. A presença e a integração do gene bar foram confirmados pelas análises de PCR e Southern blot. As plantas transgênicas selecionadas de café, pulverizadas com 1600 mg. $\mathrm{L}^{-1}$ do herbicida Finale ${ }^{\mathrm{TM}}$ que contém glufosinato como ingrediente ativo, mantiveram a coloração e continuaram crescendo normalmente na aclimatação ex vitro.

\section{REFERENCES}

Barton, C. R.; Adams, T. L. and Zarowitz, M. A. (1991), Stable transformation of foreign DNA into $C$. arabica plants. In: Colloque Scientifique sur le café ASIC, 14., San Francisco. Anais... San Francisco. pp. 460-464.

Blanco, H. G.; Oliveira, D. A. and Pupo, E. I. H. (1982), Período de competição de uma comunidade natural de mato em uma cultura de café, em formação. Biológico, 48, 9-20.

Botterman, J. and Leemans, J. (1988), Engineering herbicide resistance in plants. Trends Genet., 4, 219-221.

Christou, P.; Ford, T. L. and Kofron, M. (1991), Production of transgenic rice (Oryza sativa L.) plants from agronomically important indica and japonica varieties via electric discharge particle acceleration of exogenous DNA into immature zygotic embryos. Biotechnol., 9, 957-960.
DeBlock, M.; Botterman, J.; Vandewiele, M.; Dock, J.; Thoen, C.; Gosselé, V.; Rao, N.; Movva, C.; Thompson, M.; Van Montagu, M. and Leemans, J.; (1987), Engineering herbicide resistance in plants by expression of a detoxifying enzyme. EMBO J., 6, 2513-2518.

Devine, M. D.; Duke, S. O. and Fedtke, C. (1993), Physiology of herbicide action. Englewood Cliffs, NJ: Prentice Hall. pp. 251-294.

D'Haullin, K.; DeBlock, M. D.; Denecke, J.; Janssens, J.; Leemans, J.; Reynaerts, A. and Botterman, J. (1992), The bar gene as selectable and screenable marker in plant engineering. Methods in Enzymol., 216, 415-26.

Doyle, J. J. and Doyle, J. L. (1987), Isolation of plant DNA from fresh tissue. Focus, 12, 13-15.

Feng, Q.; Yang, M. Z.; Zheng, X. Q.; Zhen, X. S.; Pan, N. S. and Chen, Z. L. (1992), Agrobacteriummediated transformation of coffee (Coffea arabica L.). Chin J Biotechnol., 8, 255-260.

Friessleben, U.; Pohlan, J. and Franke, G. (1991), The response of Coffea arabica L. to weed competition. Café Cacao Thé., 35, 15-20.

Hatanaka, J.; Arakawa, O.; Yasuda, T.; Ushida, N. and Yamaguchi, I. (1991), Effect of plant growth regulators on somatic embryogenesis in leaf cultures of Coffea canephora. Plant Cell Rep., 10, 179-182.

Hatanaka, T.; Choi, Y. E.; Kusano, T. and Sano, H. (1999), Transgenic plants of Coffea canephora from embryogenic callus via Agrobacterium tumefaciens-mediated transformation. Plant Cell Rep., 19, 106-110.

Hooykaas, P. J. J.; Klapwijk, P. M.; Nuti, M. P.; Schilperoort, R. A. and Rörsch, A. (1977), Transfer of the Agrobacterium tumefaciens $\mathrm{Ti}$ plasmid to avirulent agrobacteria and to Rhizobium "ex planta". J. Gen. Microbiol., 98, 477-484.

Jefferson, R. A.; Kavanagh, T. A. and Bevan, M. W. (1987), Gus Fusions: $\beta$-glucuronidase as a sensitive and versatile gene fusion marker in higher plants. EMBO J., 6, 3901-3909.

Jones, P. A. and Wallis, J. (1963), A tillage study in Kenya coffee. Part III The long-term effects of tillage practices upon yield and growth of coffee. Emp. J. Exp. Agric., 31, 243-254.

Kosugi, S.; Oshashi, Y.; Nakajima, K. and Arai, Y. (1990), An improved assay for $\beta$-glucoronidase in transformed cells: methanol almost completely suppresses a putative endogenous $\beta$-glucoronidase activity. Plant Sci., 70, 133-140.

Leroy, T.; Henry, A. M.; Royer, M.; Altosaar, I.; Frutos, R.; Duris, D. and Philippe, R. (2000), Genetically modified coffee plants expressing the Bacillus thurigiensis cry1Ac gene for resistance to leaf miner. Plant Cell Rep., 19, 382-389.

Lorenzi, H. (1994), Plantas daninhas do Brasil. 4. ed. Nova Odessa: Plantarum. 440 pp. 
Metz, P.; Stiekema, W. and Nap, J. (1998), A transgene-centered approach to the biosafety of transgenic phosphinothricin-tolerant plants. Mol Breed., 4, 335-341.

Murakami, T.; Anzai, H.; Imai, S.; Saoh, A.; Nagaoka, K. and Thompson, C. J. (1986), The bialophos biosynthetic genes of Streptomyces hygroscopicus: molecular cloning and characterization of gene cluster. Mol Gen Genet., 205, 42-50.

Sambrook, J.; Fritsch, E. F. and Maniatis, T (1989) Molecular cloning: A Laboratory Manual. $2^{\text {nd }}$ ed. New York: Cold Spring Habour Laboratory Press.

Spiral, J.; Thierry, C.; Paillard, M. and Petiard, V. (1993), Obtention de plutules de Coffea canephora Pierre transformées par Agrobacterium rhizogenes. $C$. R. Acad Sci Paris., 316, 1-6.

Spiral, J.; Leroy, T.; Paillard, M. and Petiard, V. (1999), Transgenic coffee (Coffea sp.). In: Bajaj, Y. P. S. (Ed.). Biotechnology in Agriculture and Forestry. Trangenic Trees. Berlim Heidelberg: Spring-Verlag, pp. 55-76.

Strauch, E.; Wohllenben, W. and Pühler, A. (1988) Cloning of a phosphinothricin N-acetyltransferase gene from Streptomyces viridochomogenes Tü494 and its expression in Streptomyces lividans and Escherichia coli. Gene, 63, 65-74.

van Boxtel, J.; Eskes, A. and Berthouly, M. (1995), Glufosinate as an efficient inhibitor of callus proliferation in coffee tissue. In Vitro Cell. \& Develop. Biol. Plant, 33, 6-12. 